\title{
Diel Activity Patterns of the Turtle Assemblage of a Northern Indiana Lake
}

\author{
GEOFFREY R. SMITH ${ }^{1}$ \\ Department of Biology, Denison University, Granville, Ohio 43023 \\ AND \\ JOHN B. IVERSON \\ Department of Biology, Earlham College, Richmond, Indiana 47374
}

\begin{abstract}
We investigated the daily activity patterns of seven species of turtles in a northern Indiana lake over $10 \mathrm{y}$ using the numbers of captures in fyke nets as an index of activity. Chrysemys picta and Graptemys geographica were active throughout the daylight hours. Sternotherus odoratus and Chelydra serpentina were crepuscular. Trachemys scripta was diurnal; however, its activity was concentrated in the morning hours. Apalone spinifera was diurnal as well, with most activity in the afternoon and very little in the morning. Emydoidea blandingii was rarely captured, and all captures were made during daytime hours. Activity patterns did not change substantially between two sampling periods from mid-May to mid-June and from lateJuly to early-August. These activity patterns are consistent with differences in the frequency of basking: baskers are diurnal (e.g., C. picta, G. geographica, T. scripta, E. blandingii and A. spinifera), whereas those that are secretive are crepuscular (e.g., S. odoratus and C. serpentina).
\end{abstract}

\section{INTRODUCTION}

The time of day during which an organism is active can be an important facet of its biology. For example, the timing of activity can influence the physical environment an individual experiences, the potential competitors and predators it encounters and the resources that are available. For north temperate freshwater turtles, diel activity patterns during the growing season (ca. May to September) range from nocturnal to diurnal, including crepuscular patterns (see reviews in Gourley, 1979 and Graham and Hutchison, 1979).

While there is information on diel activity patterns for several freshwater turtles species, the ability to compare species may be confounded by the different techniques used (e.g., radiotelemetry, trapping), the different geographic locations of the studies and the focus on only a single species at any one locality. Our study looked at an entire assemblage of turtles from a single locality using the same technique for all species, allowing us to examine differences in diel activity patterns among species without the confounding effects of technique, locality or the focus on a single species.

We used data collected as part of a long-term study of a turtle assemblage in a large lake in northern Indiana, USA, to examine diel activity patterns for seven species of turtles: painted turtles (Chrysemys picta), common musk turtles (Sternotherus odoratus), common snapping turtles (Chelydra serpentina), red-eared sliders (Trachemys scripta), northern map turtles (Graptemys geographica), spiny softshell turtles (Apalone spinifera) and Blanding's turtles (Emydoidea blandingii). Previous studies on these species have found a diversity of activity patterns and, in fact, for some individual species (e.g., S. odoratus) different studies have reported the full range of potential activity patterns (Table 1$)$.

${ }^{1}$ Corresponding author: e-mail: smithg@denison.edu 
TABLE 1.-Literature reports of diel activity patterns of the seven turtle species found in Dewart Lake, north-central Indiana

\begin{tabular}{|c|c|c|}
\hline Species & Activity pattern & Reference \\
\hline \multirow[t]{2}{*}{ Chrysemys picta } & Diurnal & $\begin{array}{l}\text { Sexton (1959); Ernst (1971); } \\
\text { Graham and Hutchison (1979); } \\
\text { Ernst et al. (1994); Lefevre and } \\
\text { Brooks (1995); Rowe (2003) }\end{array}$ \\
\hline & Nocturnal & Rowe (2003) \\
\hline \multirow[t]{3}{*}{ Sternotherus odoratus } & Diurnal & $\begin{array}{l}\text { Mahmoud (1969; in winter); } \\
\text { Vermersch (1992; in winter) }\end{array}$ \\
\hline & Crepuscular & $\begin{array}{l}\text { Tinkle (1958); Mahmoud (1969; in summer); } \\
\text { Graham and Hutchison (1979); } \\
\text { Ernst (1986); Jackson (1988); } \\
\text { Vermersch (1992; in summer) }\end{array}$ \\
\hline & Nocturnal & $\begin{array}{l}\text { Lagler (1943); Gourley (1979; } \\
\text { "under extreme conditions"); } \\
\text { Bancroft et al. (1983); Ernst et al. (1994) }\end{array}$ \\
\hline \multirow[t]{2}{*}{ Chelydra serpentina } & Crepuscular & Obbard and Brooks (1981) \\
\hline & Nocturnal & $\begin{array}{l}\text { Carr (1952); Wade and Gifford (1965); } \\
\text { Graham (1978); Bancroft et al. (1983); } \\
\text { Minton (2001) }\end{array}$ \\
\hline \multirow[t]{2}{*}{ Trachemys scripta } & Diurnal & $\begin{array}{l}\text { Cagle (1950); Tinkle (1958); Boyer (1965); } \\
\text { Crawford et al. (1983); Gibbons et al. (1990); } \\
\text { Lindeman (2000) }\end{array}$ \\
\hline & Nocturnal & Wade and Gifford (1965) \\
\hline \multirow[t]{2}{*}{ Graptemys geographica } & Diurnal & Ernst et al. (1994) \\
\hline & Nocturnal & Wade and Gifford (1965) \\
\hline \multirow[t]{2}{*}{ Apalone spinifera } & Diurnal & Ernst et al. (1994) \\
\hline & Nocturnal & Wade and Gifford (1965) \\
\hline \multirow[t]{2}{*}{ Emydoidea blandingii } & Diurnal & Graham (1979); Rowe and Moll (1991) \\
\hline & Nocturnal & Wade and Gifford (1965) \\
\hline
\end{tabular}

\section{Materials AND Methods}

We studied the turtles in the marsh at the SE end of Station Bay in the SE corner of Dewart Lake (area of our study area $=4.5$ ha) near Syracuse (Kosciusko Co.), Indiana. Turtle populations have been studied in Dewart Lake for over 40 y (see Wade and Gifford, 1965), with relatively continuous study since 1979 (see Iverson, 1988; Smith and Iverson, 2002).

We have sampled the turtle assemblage in Station Bay nearly annually since 1979 using a variety of trapping methods. However, for this study, we restricted our analyses to those years (1993-2002) when we exclusively used fyke nets deployed with $18 \mathrm{~m}$ leads between a pair of $90 \mathrm{~cm}$ diameter hoop traps. Fyke nets were placed along the interface between a densely vegetated (Typha and Nuphar) area of Station Bay and open water near the opening of Station Bay. In most years, the entire mouth of Station Bay was blocked by the fyke nets and leads. Water depth along this interface varied among years, but usually ranged from $70 \mathrm{~cm}$ to $2 \mathrm{~m}$. Traps were usually completely submerged. Fyke nets quickly trapped fish, which probably attracted turtles; no supplementary bait was used.

Early in our study traps were checked at night, and we never captured turtles of any species between 2200 and first light. We also found that turtles at Dewart Lake showed signs of anoxia 
TABLE 2.-Distribution of traps and turtles observed and expected (in parentheses; followed by the proportional contribution to the chi-square statistic) captures for May and June (1995-1997) among times of day. Chi-square tests for each species were significant. See text for hours included in each time of day

\begin{tabular}{lccccc}
\hline \hline \multirow{2}{*}{\multicolumn{2}{c}{ Sample period }} & Traps & & & \\
\cline { 2 - 4 } & $\#$ & Prop. & C. picta & S. odoratus & G. geographica \\
\hline Dawn & 83 & 0.392 & $211(176 ; 0.087)$ & $46(42 ; 0.027)$ & $17(16 ; 0.005)$ \\
Mid-morning & 17 & 0.080 & $57(36 ; 0.152)$ & $16(9 ; 0.384)$ & $7(3 ; 0.413)$ \\
Noon & 14 & 0.066 & $7(30 ; 0.219)$ & $4(7 ; 0.091)$ & $6(3 ; 0.233)$ \\
Mid-afternoon & 44 & 0.208 & $49(93 ; 0.259)$ & $21(22 ; 0.003)$ & $6(8 ; 0.039)$ \\
Early evening & 43 & 0.203 & $119(91 ; 0.107)$ & $11(22 ; 0.388)$ & $4(8 ; 0.155)$ \\
Late-evening/Dusk & 11 & 0.052 & $5(23 ; 0.175)$ & $9(6 ; 0.106)$ & $0(2 ; 0.155)$ \\
\hline
\end{tabular}

if held in submerged nets $>3 \mathrm{~h}$ and, therefore, we checked the traps every $2-3 \mathrm{~h}$ from sunrise to $1-2 \mathrm{~h}$ post-sunset. Trap checks between $0600-0700 \mathrm{~h}$ did not produce drowned turtles, again reflecting the lack of nocturnal activity by these turtles. All captured turtles were retained and released at the end of the sampling period (2-5 d). For each trap check, we recorded the number of each species of turtle.

We sampled turtles at two times during the spring and summer. In 3 y (1995-1997) we trapped turtles during the period between mid-May and mid-June and in $10 \mathrm{y}$ (1993-2002) we trapped turtles during the period between late July and early August. We analyzed activity patterns for these two times of year separately to look for shifts in activity over the activity season.

To analyze activity distributions we partitioned the "trapping" day into six periods representing the times that the traps were checked: Dawn (0600-0900), Mid-morning (09001200), Noon (1200-1500), Mid-afternoon (1500-1800), Early evening (1800-2100) and Lateevening (2100-2400). We summed the number of trap hours over all years, as well as captures per trapping period.

Our use of captures in fyke nets as an index of activity may have some inherent minor biases; however, we feel that these do not present any major concerns for our objectives. First, it is theoretically possible for turtles to escape from the traps. However, it is unlikely that this low probability would differ among times of the day, especially since the traps were checked at regular intervals. Traps were left unchecked for long periods overnight, but our earlier work revealed no nocturnal captures. In addition, during trap checks we never observed turtles to escape from these traps once fully inside them.

If turtles were active and being captured in our traps at random times during the day, we would expect cumulative captures to be distributed in proportion to the cumulative number of traps set at that time of day. Expected capture distributions were calculated based upon the distribution of traps during the study by multiplying the total number of turtle captures for a species by the proportion of traps at a given time of day (e.g., to obtain the expected number of Chrysemys picta captures at Dawn, we multiplied 448 total captures by 0.392 to get 176; see Table 2). Comparisons of observed and expected turtle capture distributions were made using chi-square tests. In order to facilitate the interpretation of significant chi-square tests, we calculated standardized residuals for the chi-square tests (Reynolds, 1977; see also Newman and Waters, 1984). Standardized residuals have been used in dietary studies to determine selectivity for certain prey items (e.g., Newman and Waters, 1984; Mancinelli et al., 2002). A large positive standardized residual (i.e., >1) indicates greater than expected use of a particular category (in our case time of day), 


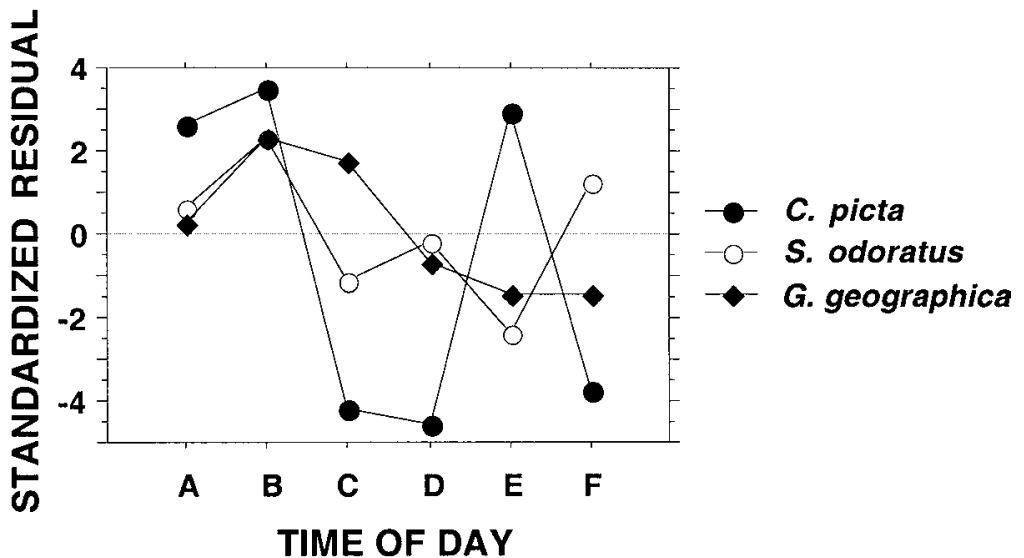

FIG. 1.-Standardized chi-square residuals for the number of captures at each time of day in May and June for three turtle species in a northern Indiana lake. Positive values indicate greater than expected values and negative values indicate less than expected values. $\mathrm{A}=$ dawn $(0600-0900), \mathrm{B}=$ mid-morning (0900-1200), $\mathrm{C}=$ noon (1200-1500), $\mathrm{D}=$ mid-afternoon (1500-1800), $\mathrm{E}=$ early evening (1800-2100), $\mathrm{F}=$ late-evening/dusk (2100-2400)

whereas a large negative standardized residual (i.e., $<-1$ ) indicates less than expected use of a particular category. A zero standardized residual means the category was used as expected. In addition, we calculated the percent contribution to the chi-square statistic for each time of day. Times of day contributing heavily to the chi-square statistic are those with the greatest deviation from the expected values.

\section{RESULTS \\ $\mathrm{MAY} / \mathrm{JUNE}$}

We made a total of 616 turtle captures in May and June from 1995-1997. Most captures were of painted turtles (Chrysemys picta; 448), followed by common musk turtles (Sternotherus odoratus; 107). We made 3 captures of Chelydra serpentina, 40 of Graptemys geographica, 3 of Apalone spinifera, 14 of Trachemys scripta and 1 of Emydoidea blandingii. Three species with sufficient captures for analysis all deviated significantly from the expected distribution of captures across the six time periods (C. picta, $\chi_{5}{ }^{2}=80.4, \mathrm{P}<0.0001 ;$ S. odoratus, $\chi_{5}{ }^{2}=14.2, \mathrm{P}=$ $0.014 ;$ G. geographica, $\left.\chi_{5}^{2}=12.9, \mathrm{P}=0.024\right)$.

Chrysemys picta captures occurred throughout the day, but they were captured more than expected at dawn, in mid-morning and in the early evening (Table 2, Fig. 1). Sternotherus odoratus activity was concentrated at mid-morning and late evening (Table 2; Fig. 1), with fewer captures than expected at noon and early-evening. Captures of Graptemys geographica were greater than expected in mid-morning and noon (Table 2; Fig. 1). During the mid-afternoon, early evening and late evening hours, captures of G. geographica were less than expected.

There were too few captures in May and June of Chelydra serpentina, Trachemus scripta, Apalone spinifera and Emydoidea blandingii to perform statistical analyses. Two of the three $C$. serpentina captures were at dawn, and the other was in the early evening. Of the 14 T. scripta captures, eight were at dawn, four were in the early evening and one was in mid-morning. The three A. spinifera captures were spread throughout the daylight hours with one each occuring at dawn, noon and mid-afternoon. The single E. blandingii capture was at dawn. 

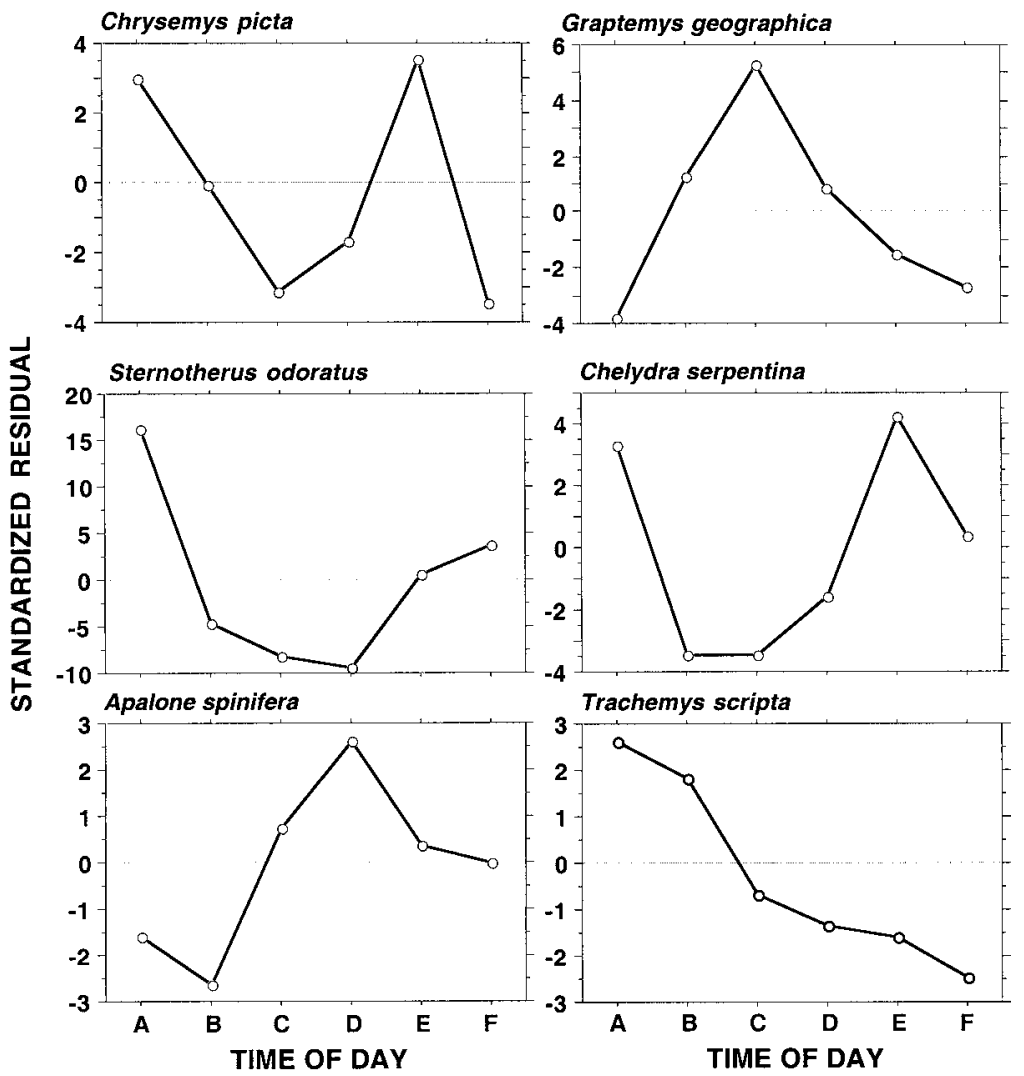

FIG. 2.-Standardized chi-square residuals for the number of captures at each time of day in July and August for six turtle species. Positive values indicate greater than expected values and negative values indicate less than expected values. $\mathrm{A}=$ dawn (0600-0900), $\mathrm{B}=$ mid-morning (0900-1200), $\mathrm{C}=$ noon (1200-1500), D = mid-afternoon (1500-1800), $\mathrm{E}=$ early evening $(1800-2100), \mathrm{F}=$ late-evening/dusk (2100-2400)

\section{JULY/AUGUST}

We made a total of 3106 turtle captures in July and August from 1993-2002. Most captures were of Chrysems picta (1889), followed by Sternotherus odoratus (815). We recorded 118 captures of Chelydra serpentina, 129 of Graptemys geographica, 40 of Apalone spinifera, 115 of Trachemus scripta and 8 of Emydoidea blandingii. For each turtle species encountered (except E. blandingii for which too few captures were made for statistical analysis), the observed activity pattern deviated significantly from the expected activity pattern $\left(C\right.$. picta, $\chi_{5}{ }^{2}=45.9, \mathrm{P}<$ 0.0001 ; S. odoratus, $\chi_{5}{ }^{2}=455.4, \mathrm{P}<0.0001$; C. serpentina, $\chi_{5}{ }^{2}=55.3, \mathrm{P}<0.0001$; G. geographica, $\chi_{5}{ }^{2}=54.2, \mathrm{P}<0.0001 ;$ A. spinifera, $\chi_{5}{ }^{2}=17.2, \mathrm{P}=0.004 ;$ T. scripta, $\left.\chi_{5}{ }^{2}=21.2, \mathrm{P}=0.0007\right)$.

Chrysemys picta captures occurred throughout the day; however, they were captured more than expected at dawn and in the early evening and less than expected at noon and lateevening/dusk (Table 3, Fig. 2). Sternotherus odoratus captures were concentrated at dawn with substantially more captures than expected (Table 3, Fig. 2). Captures in late evening/dusk were also more than expected, but there were considerably fewer captures than expected during the daylight hours. 


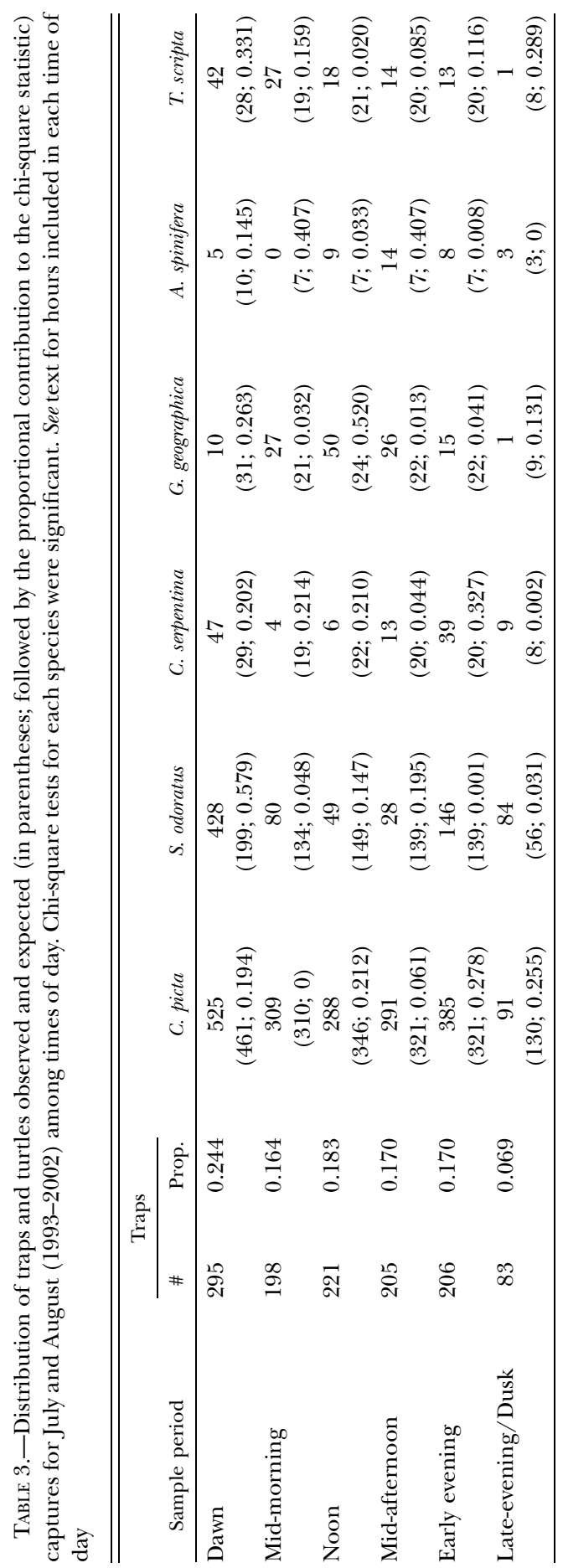


Chelydra serpentina captures were greater than expected at dawn and early evening, but as expected or less than expected at all other times of the day (Table 3, Fig. 2). Captures of Graptemys geographica were greater than expected at mid-morning, noon and mid-afternoon, but as expected during other daylight hours and less than expected at dawn and late evening/ dusk (Table 3, Fig. 2).

Apalone spinifera were rarely captured in the morning hours (dawn and mid-morning), but more were captured than expected in mid-afternoon (Table 3, Fig. 2). Trachemys scripta were captured more than expected during the morning hours (dawn and mid-morning), captured at the expected rate at noon and slightly less than expected in the afternoon and evening hours (mid-afternoon, early evening and late evening/dusk; Table 3, Fig. 2). Five of the eight Emydoidea blandingii captures were in mid-morning, two at noon and one in the early evening.

\section{Discussion}

The assemblage of turtles that we captured in Dewart Lake showed a diversity of diel activity patterns, ranging from crepuscular (Sternotherus odoratus, Chelydra serpentina) to primarily diurnal (Graptemys geographica). Some diurnal species were captured throughout the daylight hours, but captures were concentrated during a particular time of the day: Chrysemys picta had early morning and early evening peaks in activity, Trachemys scripta was active primarily in the morning and Apalone spinifera was most active in the afternoon. We found no evidence of nocturnal activity in any species.

There were no major shifts in daily activity patterns apparent between the May/June and July/August periods. Minor differences involved slight shifts between adjacent time periods (e.g., from mid-morning to dawn). Such shifts might be expected if water temperature influences activity (e.g., Graham and Hutchison, 1979) because water temperatures are typically warmer in July and August compared to May and June. One example of a minor shift in the timing of activity in our study was the earlier peak of morning activity in Sternotherus odoratus during the July/August period (dawn) compared to the May/June period (midmorning). Both Mahmoud (1969) and Vermersch (1992) reported shifts in the activity pattern of $S$. odoratus from crepuscular in the summer to diurnal in the winter.

Chrysemys picta activity occurred during the day in our study and was the most evenly distributed throughout the daylight hours of any of the turtles in this assemblage. Our results were consistent with previous studies on painted turtle daily activity patterns (Table 1), but Rowe (2003) has found some nocturnal activity in a Michigan population. In particular, our observation of an early morning pulse of activity is consistent with previous observations by Calhoun (1944; cited in Graham and Hutchison, 1979) and Graham and Hutchison (1979).

Sternotherus odoratus clearly had a crepuscular activity cycle in northern Indiana, with more activity at dawn than at dusk. Our results were consistent with most previous temperate-zone studies on $S$. odoratus that reported crepuscular activity patterns, with occasional activity during the day (Table 1). Based on laboratory studies, Graham and Hutchison (1979) suggested that this bimodal activity pattern may have been related to higher environmental temperatures, and that activity may be unimodal when water temperatures are low (see above). Musk turtles were never observed active at night despite intense nocturnal searching and/or trapping in Texas (Vermersch, 1992) or Indiana (this study), but both Carr (1952) and Bancroft et al. (1983) reported primarily nocturnal activity in Florida. Further study will be needed to determine if Florida musk turtles are indeed primarily nocturnal and, if so, whether that pattern is due to warmer water temperatures, as speculated by Ernst (1986).

Snapping turtles (Chelydra serpentina) were most active at dawn and (especially) early evening, although occasional individuals were captured through the day. Obbard and Brooks (1981) also found a crepuscular activity pattern for C. serpentina in Ontario, Canada. As for 
Sternotherus odoratus, Carr (1952) and Bancroft et al. (1983) both reported nocturnal activity for snapping turtles in Florida. Confirmation of this apparent geographic variation in behavior is needed.

Trachemys scripta had a basically diurnal activity pattern, with most activity concentrated in the morning hours (see also Cagle, 1950; Lindeman, 2000). Our results were consistent with most other studies (see Table 1). Diurnality in Trachemys scripta may reflect the temperatures these turtles need to be active, and which are reached only during the day (Boyer, 1965; Crawford et al., 1983; Bury et al., 2000). Graptemys geographica was also diurnal, which is consistent with previous studies except for Wade and Gifford (1965; see Table 1).

Activity in Apalone spinifera was concentrated in the afternoon at Dewart Lake. In Kentucky, Lindeman (2000) found that smooth softshell turtles (A. mutica) were diurnal. As with Trachemys scripta, the diurnal activity pattern found in spiny softshells may reflect water temperatures and/or the body temperatures these turtles can achieve during the day (see Nebeker and Bury, 2001 for data for the smooth softshell, A. mutica).

Although the number of captures was small, it appeared that Emydoidea blandingii was diurnal in Dewart Lake, with captures coming at most times of the day except for dawn. This was consistent with the work of Rowe and Moll (1991) in Illinois (see also Graham, 1979).

In summary, all four emydids had diurnal or modified diurnal (i.e., primarily morning or afternoon) activity patterns. Activity in softshells (Trionychidae) peaked in the late afternoon. The kinosternid and the chelydrid were primarily crepuscular. Additional research on other species and in other geographic regions is necessary to determine if these patterns of daily activity are more universal. Of particular interest is further study of the apparent latitudinal shifts in diel activity patterns in musk turtles and snapping turtles.

Acknowledgments. - We thank the many students, colleagues and family members who have helped catch turtles at Dewart Lake over the past $21 \mathrm{y}$. Funding was provided by Earlham College, Denison University and our families. We thank Quaker Haven Camp (particularly Tish and Jerry Dain) for providing access to housing, the Neffs and Mullens for storing equipment and B. Haubrich for use of his pier. The comments of P. Lindeman, T. Graham and an anonymous reviewer on an early draft are greatly appreciated.

\section{Literature Cited}

Bancroft, G. T., J. S. Godley, D. T. Gross, N. N. Rojas, D. A. Sutphen and R. W. McDiarmid. 1983. The herpetofauna of Lake Conway: species accounts. U.S. Army Corps Eng., Misc. Pap., A-83-5. Army Engineer Waterways Experiment Station, Vicksburg, Mississippi. 354 p.

BOYER, D. R. 1965. Ecology of the basking habit in turtles. Ecology, 46:99-118.

Bury, R. B., A. V. Nebeker and M. J. Adams. 2000. Response of hatchling and yearling turtles to thermal gradients: comparison of Chelydra serpentina and Trachemys scripta. J. Therm. Biol., 25:221-225.

CAgle, F. R. 1950. The life history of the slider turtle, Pseudemys scripta troosti (Holbrook). Ecol. Monogr., 20:31-54.

Calhoun, J. B. 1944. Twenty-four hour periodicities in the animal kingdom. Part II. The vertebrates. J. Tenn. Acad. Sci., 19:179-200.

CARR, A. F., JR. 1952. Handbook of turtles. The turtles of the United States, Canada, and Baja California. Comstock Publ. Assoc., Cornell University Press, Ithaca. 542 p.

Crawford, K. M., J. R. Spotila and E. A. Standora. 1983. Operative environmental temperatures and basking behavior of the turtle Pseudemys scripta. Physiol. Zool., 64:989-999.

ERnst, C. H. 1971. Population dynamics and activity cycles of Chrysemys picta in southeastern Pennsylvania. J. Herpetol., 5:151-160.

1986. Ecology of the turtle, Sternotherus odoratus, in southeastern Pennsylvania. J. Herpetol., 20:341-352. 
R. W. Barbour and J. E. Lovich. 1994. Turtles of the United States and Canada. Smithsonian Institution Press, Washington, D.C. 578 p.

Gibbons, J. W., J. L. GreEne and J. D. Congdon. 1990. Temporal and spatial movement patterns of sliders and other turtles, p. 201-215. In: J. W. Gibbons (ed.). Life history and ecology of the slider turtle. Smithsonian Institution Press, Washington, D.C.

Gourley, E. V. 1979. Rhythms, p. 509-520 In: M. Harless and H. Morlock (eds.).Turtles: perspectives and research. John Wiley and Sons, New York.

Graham, T. E. 1978. Preliminary notes on locomotor behavior in juvenile snapping turtles, Chelydra serpentina, under controlled conditions. Bull. Maryland Herpetol. Soc., 14:266-268.

- 1979. Locomotor activity in the Blanding's turtle, Emydoidea blandingii (Reptilia, Testudines, Emydidae): the phasing effect of temperature. J. Herpetol., 13:365-366.

- AND V. H. Hutchison. 1979. Turtle diel activity: response to different regimes of temperature and photoperiod. Comp. Biochem. Physiol., 63A:299-305.

Iverson, J. B. 1988. Growth in the common map turtle, Graptemys geographica. Trans. Kansas Acad. Sci., 91:153-157.

JACKSON, J. F. 1988. Crevice occupation by musk turtles: taxonomic distribution and crevice attributes. Anim. Behav., 36:793-801.

LAGLER, K. F. 1943. Food habits and economic relations of the turtles of Michigan with special reference to fish management. Am. Midl. Nat., 29:257-312.

Lefevre, K. and R. J. BRooks. 1995. Effects of sex and body size on basking behavior in a northern population of the painted turtle, Chrysemys picta. Herpetologica, 51:217-224.

Lindeman, P. V. 2000. Resource use of five sympatric turtle species: effects of competition, phylogeny, and morphology. Can. J. Zool., 78:992-1008.

Mahmoud, I. Y. 1969. Comparative ecology of the kinosternid turtles of Oklahoma. Southwest. Nat., 14:31-66.

Mancinelli, G., M. L. Costantini and L. Rossi. 2002. Cascading effects of predatory fish exclusion on the detritus-based food web of a lake littoral zone (lake Vico, central Italy). Oecologia, 133:402-411.

Minton, S. 2001. Amphibians and reptiles of Indiana. Indiana Academy of Science, Indianapolis. 400 p.

Nebeker, A. V. And R. B. Bury. 2001. Response of juvenile softshell turtles (Apalone mutica) in a thermal gradient. Chel. Conserv. Biol., 4:162-165.

Newman, R. M. and T. F. Waters. 1984. Size-selective predation on Gammarus pseudolimnaeus by trout and sculpins. Ecology, 65:1535-1545.

ObBard, M. E. and R. J. Brooks. 1981. A radio-telemetry and mark-recapture study of activity in the common snapping turtle, Chelydra serpentina. Copeia, 1981:630-637.

ReYNolds, H. T. 1977. The analysis of cross-classifications. Free Press, New York. 236 p.

Rowe, J. W. 2003. Activity and movements of midland painted turtles (Chrysemys picta marginata) living in a small marsh system on Beaver Island, Michigan. J. Herpetol., 37:342-353.

AND E. O. MoLL. 1991. A radiotelemetric study of activity and movements of the Blanding's turtle (Emydoidea blandingii) in northeastern Illinois. J. Herpetol., 25:178-185.

Sexton, O. J. 1959. Spatial and temporal movements of a population of the painted turtle, Chrysemys picta marginata (Agassiz). Ecol. Monogr., 29:113-140.

Smith, G. R. AND J. B. Iverson. 2002. Sex ratio of common musk turtles (Sternotherus odoratus) in a northcentral Indiana lake: a long-term study. Am. Midl. Nat., 148:185-189.

TinkLE, D. W. 1958. The systematics and ecology of the Sternothaerus carinatus complex. Tulane Stud. Zool., 6:3-56.

Vermersch, T. G. 1992. Lizards and turtles of south-central Texas. Eakin Press, Austin. 170 p.

WADE, S. E. AND C. E. GIFFORD. 1965. A preliminary study of the turtle population of a northern Indiana lake. Proc. Indiana Acad. Sci., 74:371-374. 